\title{
EFEK INTERVENSI TERSTRUKTUR TERHADAP PENURUNAN KELUHAN SINDROM PREMENSTRUASI
}

\author{
Hermansyah, Husni, Elly Wahyuni \\ Politeknik Kesehatan Kementerian Kesehatan Bengkulu, Jurusan Keperawatan, \\ Jalan Indragiri Nomor 03 Padang Harapan Kota Bengkulu \\ man2aditya@yahoo.com
}

\begin{abstract}
Abstrak : Approximately $40 \%$ of women aged 14-50 years experiencing pre-menstrual syndrome, better known as PMS (pre-menstruation syndrome). This study aims to determine the effect of a structured intervention (counseling and natural techniques) against reducing premenstrual syndrome complaints in young women aged 12-15 years in the city of Bengkulu. This type of research is a pre-experimental, with one group pretest posttest design. The populations in this study were all girls (191 girls) in grade one of Junior High School 2, Bengkulu city in 2013. The sample was 35 samples girls taken with accidental sampling technique. Data was collected using primary data to obtain symptom of premenstrual syndrome by using a check list format and schedule student menstruation. Data analysis was performed using univariate and bivariate statistical tests by using a dependent $\mathrm{t}$-test (paired $\mathrm{t}$ test) at $\alpha 5 \%$ (one tail ). Results obtained by univariate analysis the average complaint premenstrual syndrome experienced by young women before intervention structured is 31.29 with a standard deviation of 7.238 , the average sympton of premenstrual syndrome experienced by young women after structured interevensi is 27.86 with a standard deviation of 7.815. The results of the bivariate analysis showed a structured intervention has efffect in reducing symptom of premenstrual syndrome ( $\mathrm{p}=0.022$ ). It is suggested to do this intervention regularly in order to reduce premenstrual syndrome.
\end{abstract}

Key words : Structured intervention, pre menstrual syndrome, teenager.

Abstrak : Menurut penelitian, sekitar 40\% wanita berusia 14-50 tahun mengalami sindrom pra-menstruasi atau yang lebih dikenal dengan PMS (pre-menstruation syndrome). Penelitian ini bertujuan untuk mengetahui pengaruh intervensi terstruktur (konseling dan teknik alami) terhadap penurun keluhan sindrom premenstruasi pada remaja putri usia 12 - 15 tahun di kota Bengkulu. Jenis penelitian adalah pra-eksperimental, dengan desain one group pretest posttest. Populasi dalam penelitian ini adalah seluruh remaja putri kelas 1 SMPN 2 Kota Bengkulu tahun 2013 yang berjumlah 191 orang. Sampel penelitian berjumlah 35 sampel yang diambil dengan tehnik accidental sampling. Pengumpulan data menggunakan data primer untuk mendapat keluhaan sindrom premenstruasi dengan menggunakan format chek list dan jadwal menstruasi siswi. Analisis data dilakukan secara univariat dan bivariat dengan menggunakan uji statistik dependent t-test (Paired t test) pada $\alpha$ 5\% (one tail). Hasil analisis univariat diperoleh rata-rata keluhan sindrom premenstruasi yang dialami remaja putri sebelum interevensi terstruktur adalah 31,29 dengan standar deviasi 7,238, rata-rata keluhan sindrom premenstruasi yang dialami remaja putri sesudah interevensi terstruktur adalah 27,86 dengan standar deviasi 7,815. Hasil analisis bivariat menunjukkan ada pengaruh intervensi terstruktur terhadap penurun keluhan sindrom premenstruasi pada remaja putri di Kota Bengkulu ( $\mathrm{p}=0,022)$. Disarankan untuk melakukan intervensi ini secara teratur untuk mengurangi sindrom pramenstruasi

Kata kunci : Intervensi terstruktur, sindrom pre menstruasi, remaja 
Premenstrual syndrome (PMS) adalah kombinasi gejala yang terjadi sebelum haid dan menghilang dengan keluarnya darah menstruasi serta dialami oleh banyak wanita sebelum awitan setiap siklus menstruasi (Brunner dan Suddarth, 2001). Insidensi atau angka kejadian dari sindrom pre menstruasi sekitar 80 persen. Studi epidemiologi menunjukkan kurang lebih 20 persen dari wanita usia reproduksi mengalami gejala PMS sedang sampai berat. Sekitar 3-8 persen memiliki gejala hingga parah yang disebut $d y s-$ phoric disorder (PMDD, premenstrual dysphoric disorder) (Freeman, 2007).

Sekitar $40 \%$ wanita berusia 14-50 tahun mengalami sindrom pra-menstruasi. Hasil penelitian di Turki didapatkan bahwa dari 379 wanita yang berusia 15-49 tahun, $79 \%$ mengalami keluhan PMS dari sedang sampai berat. Keluhan utama yang dialami berupa nyeri payudara $(39,4 \%)$, low back pain (47,5\%), irritability (44,3 \%), fatigue $(54,9 \%)$, keluhan lain adalah perubahan pola tidur dan depresi (Ozturk, 2011)

Keluhan premenstruasi tersebut sudah dialami wanita sejak pertama kali haid (menarche). Usia menarche ini dimulai pada fase remaja berkisar antara 9 sampai 14 tahun. Pada masa ini khususnya remaja putri akan mengalami perubahan fisik yang pesat, sebagai pertanda biologis dari kematangan seksual (pubertas) yang merupakan masa transisi antara masa kanak-kanak dan masa reproduksi (Wiknjosastro, 2006).

Ada banyak faktor yang diduga menjadi penyebab timbulnya keluhan premnstruasi yaitu kadar hormon estrogen yang berlebihan, perubahan ratio kadar hormone estrogen/progesterone dan pe-ningkatan aktivitas hormon aldosteron, re-nin angiotensin serta hormon adrenal (Agustina, 2010). Hasil penelitian di Thailand didapatkan berbagai faktor penyebab PMS: sosio demografi, faktor gaya hidup seperti stress dan kebutuhan tidur (Thu, 2006)

PMS mempengaruhi aspek sosial dan ekonomi penderita, hubungan dengan rekan kerja, keluarga dan teman. Hasil penelitian di United Kingdom di dapatkan 5-10\% wanita menderita keluhan PMS yang hebat
(PMDD) yang berdampak pada pekerjaan, hubungan dan kehidupan sosial.

Penelitian Borenstein, dkk pada 436 wanita usia 18-45 tahun di California selatan, didapatkan penderita PMS 125 orang dengan perincian 78 orang mengalami gejala hanya pada 1 siklus menstruasi, 47 orang dengan gejala pada 2 siklus menstruasi dan 311 orang wanita normal sebagai kelompok kontrol. Wanita dengan PMS ini dinyatakan mempunyai tingkat absensi yang tinggi ( $>2$ hari kerja/bulan), Produktifitas menurun ( $>5$ hari kerja/bulan dengan $50 \%$ penurunan produktifitas), gangguan terhadap lingkungan serta aktivitas sosial ( > 14 hari/bulan) dan sering berkunjung ke pusat kesehatan rawat jalan dengan total biaya dalam 2 tahun sekitar \$ 500. Hasil penelitian di Pematang Siantar terhadap pekerja pabrik korek api didapatkan bahwa ada perbedaan rata-rata produktivitas pada saat sindrom premenstruasi dan produktivitas diluar siklus dengan $\mathrm{p}<$ 0,05 (Pujiastuti, 2007)

Terapi non farmakologi memegang peranan penting dalam penanganan PMS berupa edukasi penderita, terapi suportif dan modifikasi gaya hidup. Secara singkat, beberapa tindakan dapat dilakukan untuk mengurangi gejala PMS yaitu: pola nutrisi yang sehat (rendah lemak dan garam, tinggi protein, vitamin dan mineral). Perbanyak porsi buah-buahan, sayur mayur, gandum yang tinggi serat. Jika diperlukan, dapat ditambahkan makanan kesehatan (food supplement) yang berupa multivitamin seperti kalsium yang dapat mengurangi rasa kram, Vitamin $\mathrm{E}$ untuk mengurangi rasa nyeri pada payudara, keletihan dan insomnia serta Vitamin B6 untuk mengatasi keletihan, iritabilitas dan mood swings. Hindari makanan dengan kadar garam tinggi, makanan manis, kafein, alcohol, selalu melakukan olahraga rutin, tidur cukup minimal 8 jam/hari. Hindari rokok dan stress berkepanjangan (Hembing, 2010).

Hasil penelitian di United Kingdom terhadap 114 wanita didapatkan bahwa efektifitas treatment untuk mengurangi keluhan PMS adalah exercise $89,4 \%$, masase $80 \%$, istirahat $93,3 \%$ dan mengurangi gula $73,6 \%$ 
(George, 2000). Hasil penelitian Jacobs, T.S (2000) didapatkan bahwa dari kalsium efektif mengatasi empat gejala utama PMS yaitu: afek negatif, retensi air, hasrat makan dan nyeri pada 15 dari 17 wanita yang mengalami keluhan.

Pendidikan tentang sindrom premenstruasi merupakan suatu komponen kunci dari terapi. Pemahaman penyakit, gejala serta kondisi yang dapat diobati, hal ini saja dengan sendirinya bersifat terapeutik (Rayburn, 2001 ; Min, 2002 \& Morse (1999). Menurut Ozturk bahwa gejala PMS bisa diturunkan secara bermakna pada saat perawat memberikan edukasi pada wanita. Wanita yang baik keseimbangan psikoemosionalnya, menganggap menstruasi sebagai hal yang wajar, tidak mudah menderita sindrom premenstruasi. Sebaliknya, wanita psikoneurotik lebih mudah menunjukkan gejala-gejala yang berlebihan (Wiknjosastro, 2006).

Jumlah remaja putri usia 15-19 tahun di kota Bengkulu sebanyak 77,596 orang (Profil kesehatan provinsi Bengkulu, 2012). Diperkirankan sekitar 31.037 orang menderita PMS (40\%). Salah satu SMP di Kota Bengkulu yang memiliki jumlah siswi terbanyak dari 24 SMP yang ada adalah SMPN 2 yaitu sejumlah 544 siswi. Sementara itu siswi kelas 1 yang merupakan kelompok usia awal yang mulai menderita sindrom premenstruasi, berjumlah 191 orang. Pada tahun 2012 ada 143 kunjungan siswi ke ruangan UKS karena keluhan sindrom pre menstruasi dan pada tahun 2013, sampai bulan agustus berjumlah 71 kunjungan.

Sehubungan dengan hal tersebut perlu dilakukan penelitian tentang intervensi yang tepat untuk menurunkan keluhan PMS dengan efek lanjutan peningkatan pengetahuan dan keterampilan remaja putri dalam mengatasi keluhan PMS sejak awal agar tidak mengganggu kegiatan sekolah dan seharihari.

\section{BAHAN DAN CARA KERJA}

Desain Penelitian ini adalah praeksperimental, dengan one group pretest posttest. Sebelum dan sesudah perlakuan, dilakukan pengukuran keluhan terhadap ke- lompok eksperimen, kemudian dilakukan perbandingan pada kedua hasil pengukuran.

Populasi penelitian adalah seluruh remaja putri kelas 1 SMPN 2 Kota Bengkulu tahun 2013 yang berjumlah 191 orang. Teknik pengambilan sampel digunakan accidental sampling dengan kriteria inklusi : usia 1215 tahun, mengalami sindrom premenstruasi, bersedia menjadi responden penelitian. Berdasarkan perhitungan sampel berjumlah 35 orang.

Pengumpulan data keluhan premenstruasi menggunakan format chek list. yang disusun oleh Pujiastuti (2007) terdiri dari pengukuran fisik dan psikis meliputi 14 gejala yang dialami meliputi : tertekan/putus asa, gelisah/gembira tanpa sebab, sedih, mudah marah, malas aktifitas, sulit konsentrasi, mudah lelah, selera makan menurun/meningkat, mudah/susah mengantuk, sakit kepala, nyeri sendi, bengkak payudara, nyeri perut dan berat badan meningkat. Gejala yang dialami menggunakan likert dalam tingkat 1-4 (tidak merasakan gejala, ringan, sedang berat). Skor tertinggi 56 dan terendah 14.

Pelaksanaan konseling 1 kali menggunakan modul yang dimodifikasi peneliti. Pemberian teknik alami diberikan dengan konseling dan simulasi terdiri senam, teknik relakasasi, masase dan teknik pernafasan dalam, kompres hangat dan terapi jus. Teknik relaksasi dan senam bersumber dari Dalton dan Nina. Penggunaan dan cara pembuatan terapi jus bersumber dari Hembing. Standar operasional kerja terapi alamiah diberikan pada masing-masing siswa. Analisis data menggunakan uji $T$ Paired menggunakan bantuan komputer pada $\alpha 5 \%$ (one tail).

HASIL

\section{Analisis Univariat}

Analisis univariat pada penelitian ini menggambarkan keluhan sindrom premenstruasi pada remaja putri sebelum dan sesudah intervensi.

Tabel 1. menunjukkan bahwa sebelum intervensi rata-rata keluhan sindrom premenstruasi yang dialami responden adalah 31,29 dengan standar deviasi 7,238. Dari hasil 
estimasi interval disimpulkan bahwa 95\% diyakini rata-rata keluhan sindrom premenstruasi yang dialami responden adalah antara 28,80 sampai dengan 33,77 . Setelah intervensi, rata-rata keluhan sindrom premenstruasi yang dialami responden adalah 27,86 dengan standar deviasi 7,815. Dari hasil estimasi interval disimpulkan bahwa $95 \%$ diyakini rata-rata keluhan sindrom premenstruasi yang dialami responden adalah antara 25,17 sampai dengan 30,54.

Tabel 1. Distribusi Responden Berdasarkan Keluhan Sindrom Premenstruasi Pada Remaja Putri Intervensi di SMP 2 Bengkulu

\begin{tabular}{|c|c|c|c|c|c|c|}
\hline $\begin{array}{c}\text { Keluhan } \\
\text { Sindrom } \\
\text { Premens- } \\
\text { truasi } \\
\end{array}$ & $\mathbf{N}$ & Mean & Median & SD & $\begin{array}{l}\text { Min- } \\
\text { Mak }\end{array}$ & $\begin{array}{c}95 \% \mathrm{CI} \\
\text { for } \\
\text { Mean }\end{array}$ \\
\hline $\begin{array}{l}\text { Sebelum } \\
\text { intervensi }\end{array}$ & 35 & 31,29 & 22 & 7,238 & $18-44$ & $\begin{array}{l}28,80- \\
33,77\end{array}$ \\
\hline $\begin{array}{l}\text { Sesudah } \\
\text { Intervensi }\end{array}$ & & 27,86 & 28 & 7,815 & $15-43$ & $\begin{array}{l}25,17- \\
30,54 \\
\end{array}$ \\
\hline
\end{tabular}

\section{Analisis Bivariat}

Analisis bivariat digunakan untuk menjelaskan pengaruh intervensi terstruktur (konseling dan teknik alami) terhadap penurun keluhan sindrom premenstruasi pada remaja putri usia 12 - 15 tahun di kota Bengkulu dengan menggunakan uji dependent $t$ test.

Sebelum dilakukan uji statistik pada analisa bivariat perlu dilakukan uji normalitas data terhadap keluhan sindrom premenstruasi sebelum dilakukan intervensi dan sesudah intervensi. Apabila pada uji normalitas nilai $p>0,05$, berarti data berdistribusi normal sehingga analisis data dapat dilakukan secara parametrik yaitu dengan menggunakan uji dependent $t$-test.

\section{Uji normalitas data}

Uji normalitas data dilakukan terhadap keluhan sindrom premenstruasi pada remaja putri sebelum dan sesudah di-lakukan intervensi di SMPN 2 Kota Bengkulu.

Berdasarkan hasil uji normalitas pada tabel 2. didapatkan bahwa data keluhan sindrom premenstruasi pada remaja putri sebelum intervensi berdistribusi normal (nilai $\mathrm{p}=0,200>\alpha 0,05)$. Sedangkan data keluhan sindrom premenstruasi pada remaja putri sesudah intervensi juga berdistribusi normal $(\mathrm{p}=0,200>\alpha 0,05)$. Berdasarkan hal tersebut, maka uji statistik untuk mengetahui pengaruh intervensi terstruktur terhadap penurun keluhan sindrom premenstruasi pada remaja putri usia 12 - 15 tahun di Kota Bengkulu dapat dilanjutkan dengan menggunkan uji dependent t-test.

Tabel 2. Uji Normalitas Data Keluhan Sindrom Premenstruasi Pada Remaja Putri di SMPN 2 Kota Bengkulu

\begin{tabular}{lccc}
\hline \multicolumn{1}{c}{ Variabel } & N & Statistic & $\boldsymbol{p}$ \\
\hline $\begin{array}{l}\text { Sebelum Inter- } \\
\text { vensi }\end{array}$ & 35 & 0,110 & 0,200 \\
$\begin{array}{l}\text { Sesudah Inter- } \\
\text { vensi }\end{array}$ & 35 & 0,100 & 0,200 \\
\hline
\end{tabular}

Tabel 3. Analisis Pengaruh Intervensi Terstruktur terhadap Penurun Keluhan Sindrom Premenstruasi Pada Remaja Putri di SMPN 2 Kota Bengkulu

\begin{tabular}{|c|c|c|c|c|c|}
\hline Kelompok & $\mathbf{N}$ & Mean & SD & $\begin{array}{c}\mathbf{t} \\
(\mathbf{d f})\end{array}$ & $p$ \\
\hline $\begin{array}{l}\text { Sebelum } \\
\text { Intervensi }\end{array}$ & 35 & 31,29 & 7,238 & \multirow{2}{*}{$\begin{array}{c}2,409 \\
(34)\end{array}$} & \multirow{2}{*}{0,022} \\
\hline $\begin{array}{l}\text { Sesudah } \\
\text { Intervensi }\end{array}$ & 35 & 27,86 & 7,815 & & \\
\hline
\end{tabular}

Berdasarkan tabel 3. dapat diketahui bahwa terdapat penurunan rata-rata keluhan sindrom premenstruasi pada remaja putri dari 31,29 sebelum dilakukan intervensi menjadi 27,86 setelah diberikan intervensi yaitu sebesar 3,43. Hasil uji statistik juga menunjukkan bahwa terdapat pengaruh intervensi terstruktur terhadap penurun keluhan sindrom premenstruasi pada remaja putri $(\mathrm{p}=0,022)$.

\section{PEMBAHASAN}

\section{Keluhan Sindrom Premenstruasi Pada Rema- ja Putri di SMPN 2 Bengkulu.}

Hasil penelitian menunjukkan bahwa sebelum intervensi rata-rata keluhan sindrom premenstruasi yang dialami responden adalah 31,29 dengan standar deviasi 7,238. Dari hasil estimasi interval disimpulkan bahwa $95 \%$ diyakini rata-rata keluhan sin- 
drom premenstruasi yang dialami responden adalah antara 28,80 sampai dengan 33,77.

Hasil penelitian tersebut menunjukkan bahwa remaja putri di SMPN 2 mengalami keluhan sindrom premenstruasi dengan skore rata-rata di atas nilai tengah skore yaitu 28 dari total skore tertinggi dari keluhan sindrom premenstruasi yaitu sebesar 56. Sindrom pramenstruasi/Premenstrual Syndrom (PMS) adalah gangguan yang dipicu oleh perubahan hormonal satu sampai dua minggu sebelum haid. Diperkirakan 40 juta wanita mengalaminya dan lebih dari 5 juta memerlukan perawatan medis. Gejala ini akan berkurang dan menghilang sampai terjadinya haid (Edward, 2006).

Insidensi atau angka kejadian dari sindrom pre menstruasi 80 persen. Studi epidemiologi menunjukkan kurang lebih 20 persen dari wanita usia reproduksi mengalami gejala PMS sedang sampai berat (Freeman, 2007). Sekitar 3-8 persen memiliki gejala hingga parah yang disebut dysphoric disorder (PMDD, Premenstrual Dysphoric Disorder). Sindroma premenstruasi terjadi pada sekitar 70-90\% wanita pada usia subur. Lebih sering ditemukan pada wanita berusia 20-40 tahun. Sindrom pra-menstruasi merupakan kumpulan gejala yang muncul antara 1 hingga 14 hari sebelum masa menstruasi dan biasanya berhenti saat menstruasi mulai. Gejala ini biasa ditandai dengan keluhan fisiologis yang menyerang segala sistem tubuh maupun gejala psikologis yang mencetuskan masalah mental dan emosional, seperti mudah marah, merasa kurang percaya diri atau lebih parah mendekati depresi.

Keluhan premenstruasi tersebut sudah dialami wanita sejak pertama kali haid (menare). Usia menare ini dimulai pada fase remaja berkisar antara 9 sampi 14 tahun. Pada masa remaja khususnya remaja putri akan mengalami perubahan fisik yang pesat, sebagai pertanda biologis dari kematangan seksual. Perubahan ini terjadi pada satu masa disebut masa pubertas, yang merupakan masa transisi antara masa kanak-kanak dan masa reproduksi (Wiknjosastro, 2006). Gangguan kesehatan berupa pusing, depresi, perasaan sensitif berlebihan sekitar dua minggu sebelum haid biasanya dianggap hal yang wajar bagi wanita usia produktif.

Gejala sindroma pramenstruasi sangat beragam, namun yang pasti kesemuanya itu berhubungan dengan perubahan hormon yang memicu terjadinya ketidakstabilan emosi dalam diri masing-masing wanita, dan biasanya gejala ini akan menghilang dengan sendirinya jika wanita telah mendapatkan haid.

\section{Pengaruh Intervensi Terstruktur terhadap Penurun Keluhan Sindrom Premenstruasi Pada Remaja Putri}

Hasil penelitian menunjukkan bahwa terdapat penurunan rata-rata keluhan sindrom premenstruasi pada remaja putri dari 31,29 sebelum dilakukan intervensi menjadi 27,86 setelah diberikan intervensi yaitu sebesar 3,43. Hasil uji statistik juga menunjukkan bahwa terdapat pengaruh intervensi terstruktur terhadap penurun keluhan sindrom premenstruasi pada remaja putri $(\mathrm{p}=0,022)$.

Intervensi terstruktur yang diberikan pada responden penelitian terdiri dari konseling dan teknik alami. Tindakan terdiri dari Pengkajian keluhan nyeri fisik dan psikologis, mereview pengetahuan tentang menstruasi dan sindrom pre menstruasi; memberikan Konseling tentang : pengertian menstruasi dan sindrom pre menstruasi, penyebab, keluhan/gejala premenstruasi, faktor resiko keluhan premenstruasi, dampak keluhan pre menstruasi, dan upaya mengatasi keluhan dan pencegahan keluhan pre menstruasi; menjelaskan dan mendemonstrasikan terapi alamiah untuk mengatasi keluhan : tehnik relaksasi, kompres hangat, dan terapi non farmakologis, dan mengevaluasi pengurangan keluhan sindrom pre menstruasi. Dengan konseling dan tehnik alami terbukti secara bermakna dapat menurun keluhan sindrom pre menstruasi pada remaja putri di SMPN 2 Kota Bengkulu.

Hasil penelitian sejalan dengan pendapat Hembing (2010), bahwa sindrom premenstruasi sebenarnya bukan merupakan masalah fisik saja, penderita harus meredakan gejala-gejalanya sendiri. Tindakan yang dapat dilakukan oleh penderita adalah olahraga 
ringan, seperti : jalan kaki dan bersepeda/berenang, yang dilakukan teratur 3 kali seminggu selama 20-30 menit; diet rendah lemak, garam dan gula tapi tinggi protein dan serat untuk mengurangi kelebihan estrogen dan pembengkakan payudara; konsumsi makanan yang kaya senyawa anti-pms : serat kasar (buah, sayur, kacang-kacangan, padipadian), vit b6 (ikan segar, tuna, hati, kacang-kacangan, beras merah, alpukat pisang), zinc (hati, kerang, ikan salamon, ayam, lobster), kalsium (kedelai, tempe, tahu, teri, ikan sarden kaleng), magnesium (lalap mentah sayuran hijau, apel, kacang mede, kedelai, tempe, makanan laut); hindari makanan dan minuman yang mengandung kefein, alkohol, dan nikotin selama 2 minggu sebelum menstruasi; minum hingga 8 gelas cairan setiap hari; tidur dengan baik pada malam hari, jika tidur malam terganggu cobalah tidur pada siang hari; lakukan tehnik relaksasi seperti menarik nafas dalam-dalam, berendam air hangat.

Hasil penelitian sejalan dengan penelitian Abraham (1984, dalam Pujiastuti, 2007), bahwa penambahan nutrisi tertentu disertai perubahan pola makan 1-2 minggu menjelang menstruasi dapat mengurangi gejala sindroma pramenstruasi. Komposisi nutrisi yang dianjurkan bagi penderita sindroma pramenstruasi adalah diet rendah lemak dan garam, mengandung protein, vitamin, mineral (Vitamin B, Vita-min C. Vitamin E, Ca, $\mathrm{Mg}, \mathrm{Zn}$ ) yang seimbang serta dianjurkan untuk mengurangi konsumsi kafein (kopi, teh).

Para penderita sindroma pramenstruasi sebaiknya melakukan olahraga secara teratur serta menghindari stres berkepanjangan. Terapi suportif seperti hipnoterapi, terapi warna, meditasi, fitopharmaca, relaksasi dan lainnya dapat membantu mengurangi gejala yang dirasakan. Teknik relaksasi dapat mengurangi tekanan dan gejala-gejala sindroma

\section{DAFTAR RUJUKAN}

Agustina, 2010. Pengaruh pemberian makanan tambahan dibandingkan dengan pemberian suplemen zat besi terhadap peningkatan produktivitas tenaga kerja wanita di industri pra menstruasi. Teknik relaksasi seperti latihan menarik nafas dalam-dalam terbukti mempunyai efek terapeutik dalam pengurangan gejala sindroma pramenstruasi.

Menurut Rayburn (2001), pendidikan tentang sindrom premenstruasi adalah suatu komponen kunci dari sembarang terapi. Pengesahan dengan gejala-gejala dan penenteraman bahwa penyakitnya adalah suatu kondisi yang dapat diobati hal ini saja dengan sendirinya bersifat terapeutik. Menurut Wiknjosastro (2006), wanita yang baik keseimbangan psikoemosionalnya, menganggap menstruasi sebagai hal yang wajar, tidak mudah menderita sindrom premenstruasi. Sebaliknya, wanita psikoneurotik yang menganggap menstruasi sebagai suatu kelainan, lebih mudah menunjukkan gejala-gejala yang berlebihan.

Jika dibandingkan dengan terapi farmakologi, konseling dan teknik alami yang merupakan terapi non farmakologi ini jauh lebih efektif dikarenakan tindakan ini tidak hanya mengatasi gejala saat keluhan terjadi terapi juga mencegah supaya keluhan tidak berkelanjutan. Sementara terapi farmakologi hanya menghilangkan gejala sesaat, obat yang biasa digunakan adalah golongan analgetik ringan namun penggunaan obat ini harus hati-hati bagi penderita gastritis karena mengakibatkan nyeri lambung.

\section{KESIMPULAN}

Hasil penelitian dapat disimpulkan bahwa rata-rata keluhan sindrom premenstruasi yang dialami remaja putri sebelum interevensi terstruktur adalah 31,29 dengan standar deviasi 7,238 , rata-rata keluhan sindrom premenstruasi yang dialami remaja putri sesudah interevensi terstruktur adalah 27,86 dengan standar deviasi 7,815. Ada pengaruh intervensi terstruktur terhadap penurun keluhan sindrom premenstruasi pada remaja putri di Kota Bengkulu.

karet Medan tahun 2001. Thesis. diunduh 1 April 2013.

Brunner \& Suddarth's, 2001. Textbook of Medical surgical nursing. Eighth Edition. Philadelphia. New York: Lippincortt. 
Freeman, E.W., 2007. Premenstrual Syndrome : Current Perspective On Treatmen and Etiology. Curr Opin Obstet Gynecol.

Hembing, 2010. Mengatasi sindrom premenstruasi (PMS) dan nyeri menstruasi secara alami.www.portal.cbn.net.id. diunduh 1 April 2013

Jacobs, T.S (2000).Micronutrienst and premenstrual syndrome: the case for calcium. Journal of American College of Nutrition vol 19.no.2. 220-227.

Rayburn, W., 2007. Obstetri dan Ginekologi. Jakarta : Widya Medika

Ozturk.S (2011). Premenstrual syndrom and management behavior in Turkey. Australian journal of Advand Nursing vol 28. No.3.

Pujiastuti, A. 2007. Pengaruh Pre Menstrual Syndrom Terhadap Produktivitas Tenaga Kerja Wanita di Pabrik Korek Api Pematang Siantar tahun 2007. Makalah tidak dipublikasikan. Diunduh 1 April 2013

Thu. M, Ore.E and Sawhsarkapaw, 2006. Premenstrual syndrome among female university student in Thailand. Journal AV J.T 9 (3): 158162.

Wald A (2011). Dietary B vitamin intake and incident premenstrual syndrom. Journal Am J clin nutr.93:1080.

Wiknjosastro. 2006. Ilmu Kebidanan. YBP-SP. Jakarta

Zulaikha, F,L,T 2010. Hubungan Pengetahuan Kesehatan Reproduksi Remaja Putri Terhadap Sikap Menghadapi Premenstrual Syndrome di SMA N 5 Surakarta. Makalah tidak dipublikasikan diunduh 1 April 2013 